\title{
Mosaic tetrasomy 9p: a mendelian interferonopathy associated with pediatric-onset overlap myositis
}

\author{
M-L Frémond ${ }^{1}$, C Gitiaux ${ }^{1}$, D Bonnet ${ }^{1}$, T Guiddir $^{2}, Y$ Crow $^{3}, \mathrm{~L}$ de Ponthual ${ }^{2}$, B Bader-Meunier $^{1 *}$ \\ From 8th International Congress of Familial Mediterranean Fever and Systemic Autoinflammatory Diseases \\ Dresden, Germany. 30 September - 3 October 2015
}

\section{Background and objectives}

Pediatric-onset inflammatory myositis (IM) and systemic lupus erythematosus (SLE) are rare inflammatory diseases. They result from the complex interaction between genetic and environmental factors. An increasing number of Mendelian conditions predisposing to the development of SLE have been recently identified. They mostly include monogenic conditions, especially type I interferonopathies, associated with an up-regulation of type I interferon (IFN), a key cytokine in SLE and some IM pathogenesis.

\section{Methods}

Report on a pediatric-onset overlap myositis in a 6-yearold girl who carries mosaic tetrasomy 9p.

\section{Results}

The patient presented with myositis overlapping with lupus-like features. Myositis was characterized by a proximal muscular weakness and HLA class I antigens myofiber overexpression on muscle biopsy. Lupus-like manifestations consisted in pericarditis, pleuritis, and positive ANA and anti-SSA antibodies. Complete remission was achieved with three pulses of methylprednisolone, followed by an oral course of steroids in combination with mycophenolate mofetyl. Analysis of tetrasomy $9 p$ showed mosaic tetrasomy in 9p24.3p12 region, including the type I IFN cluster, and increased expression of interferon (IFN)-regulated genes was found.

\section{Conclusion}

These data suggest that mosaic tetrasomy $9 p$ isa new monogenic interferonopathy predisposing to inflammatory myositis and lupus-like features. Therefore, unexplained inflammatory muscle or other organ involvement in patients carrying mosaic tetrasomy of the type IFN cluster

${ }^{1}$ Hôpital Necker, Paris, France

Full list of author information is available at the end of the article of chromosome 9p should lead to the search for IM and/ or lupus-like disease, and karyotype should be performed in SLE or IM patients with mental retardation.

\section{Authors' details}

${ }^{1}$ Hôpital Necker, Paris, France. ${ }^{2}$ Hôpital Jean Verdier, Bondy, France. ${ }^{3}$ Institut Imagine, Paris, France.

Published: 28 September 2015

doi:10.1186/1546-0096-13-S1-P140

Cite this article as: Frémond et al:: Mosaic tetrasomy 9p: a mendelian

interferonopathy associated with pediatric-onset overlap myositis. Pediatric Rheumatology 2015 13(Suppl 1):P140.
Submit your next manuscript to BioMed Central and take full advantage of:

- Convenient online submission

- Thorough peer review

- No space constraints or color figure charges

- Immediate publication on acceptance

- Inclusion in PubMed, CAS, Scopus and Google Scholar

- Research which is freely available for redistribution
() Biomed Central 